\title{
Opetusalan ammattilaisten heimoutunut työkulttuuri
}

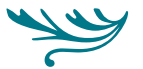 \\ Kimmo Mäki ( 2012). Opetustyön ammattilaiset ja mosaiikin mestarit. \\ Työkulttuurit ammattikorkeakouluopettajan toiminnan kontekstina. \\ Jyväskylän yliopisto. Jyväskylä Studies in Business and Economics 109.
}

MILLAISIA ASIANTUNTIJAYHTEISÖJÄ suomalaiset ammattikorkeakoulut ovat? Tein tähän lektioni alkujohdatukseksi pienen ja erittäin valikoidun kierroksen internetissä ja katsoin, mitä talot haluavat kertoa itsestään etsijälle.

Ammattikorkeakoulu X kertoo seuraavaa:

"Olemme aktiivisia vaikuttajia ja yhteistyökumppaneita. Yhdessä tekemällä saavutamme aitoa lisäarvoa. Asiantuntijuus ja työyhteisö tukevat ja mahdollistavat tekemisen. Opiskelijamme ja henkilökunta oppivat jatkuvasti tekemisen kautta. Siirrämme teoreettisen osaamisen käytännön ratkaisuihin ja liiketoiminnaksi. Tekemisemme on tavoitteellista. AMK $X: l l a ̈$ on osaava, tavoitteellinen ja uudistumiskykyinen henkilöstö. Työ AMKX:ssä on merkityksellistä, hallittua sekä yhteisöllistä. Lähtökohtana on integroida asiantuntijaorganisaation henkilökunta ja opiskelijat saumattomasti osaksi aluekehitystyötä. Toimintaamme ohjaavina arvoina ovat kehittämiskumppanuus, asiakastyytyväisyys, ihmiset voimavarana sekä tekemisen meininki toiminnassa."
Ammattikorkeakoulu Y esittäytyy seuraavasti:

"Ammattikorkeakoulu Y antaa menestymisen avaimet luomalla uutta ja kansainvälistä osaamista. Ammattikorkeakoulu $Y$ tuottaa ajanmukaista osaamista koulutuksella sekä siihen liittyvällä käyttäjälähtöisellä tutkimus-, kehittämis- ja innovaatiotoiminnalla. Työelämäkorkeakouluna Y vahvistaa toiminta-alueidensa menestystä ja uudistumista monialaisuuttaan hyödyntämällä. Arvot ovat:

- yhteisöllisyys

- yksilön ja erilaisuuden kunnioittaminen

- kestävä kehitys

- osaamisen ja yrittämisen arvostaminen

Sitoudumme yhteisiin tavoitteisiin, pyrimme opiskelijoiden menestykseen ja yhteisön hyvinvointiin, toimimme yrittäjämäisellä asenteella koko Y:n parhaaksi."

Millaisia mielikuvia, ajatuksia ja näkymiä lukijalle tulee edellisistä mieleen? AMK-organisaatiot luovat 
kuvaa asiantuntijayhteisöistään, jossa on uudistava, käytäntöä ja teoriaa yhdistävä työskentelykulttuuri ja toimintatavat ovat yhteisöllisiä sekä avoimia. Onko tämä koko kuva isosta organisaatiosta? Organisaatiosta, joka on levittäytynyt toimipisteineen mahdollisesti yli kaupunki tai maakuntarajojen. Organisaatiosta, joka on muodostunut kahden vuosikymmenen aikana aikaisemmista ammatillisista opistoista ja ammattikorkeakouluista. Organisaatiosta, jonka opettajien työhistoria vaihtelee ammatillisten opistojen opettajakokemuksista tuoreisiin elinkeinoelämän työkokemuksiin. Organisaatiosta, joka pyrkii integroimaan pedagogisen työn, tutkimus- ja kehittämistyön sekä aluekehitystehtävän toiminnassaan.

Riittävätkö meille informaatioksi ammattikorkeakoulun yhteisöstä organisaatiokulttuuria muokkaava julkipuhe netin, pr-dokumenttien ja juhlapuheiden välityksellä? Kuvaavatko ne todellista ihmisten, tässä tapauksessa opettajien (mekin olemme luonnollisesti ihmisiä) yhteisöä? Ymmärrämmekö tämän kautta, miten siellä sitoudutaan, kehitetään osaamista, toimitaan yksin tai yhdessä ja kuinka johtaminen tukee tai on tukematta kaikkea toimintaa? Kuinka yhteisöllisiä yhteisöt voivat todella olla näin monitaustaisessa organisaatiossa?

Luonnollisesti edellä, ehkä provokatiivisestikin käyttämäni tekstit irrotettuna asiayhteyksistään, eivät anna koko kuvaa moninaisesta yhteisöstä. Elämä, saatikka opettajayhteisöjen elämä ei ole näin yksinkertaista.

Jotta pääsisimme kohti tarkoitustani, lainaan filosofi Maija-Riitta Ollilaa:

"Kansalaisyhteiskunnan erilaiset instituutiot määrittelevät yksilön identiteettiä samoin kuin lähiverkostot, perhe, suku ja ystävät. Tällaisessa maailmassa osallistumme samanaikaisesti lukuisiin erilaisiin laumoihin, joihin samaistumme vaihtelevilla voimakkuuksilla. Joidenkin laumojen jäsenyydet ovat pysyvähköjä, kun taas toisissa vierailemme lyhyen hetken. Kaikista näistä laumoista omaksumme joitakin arvoja osaksi omaa persoonallisuuttamme joko pitkäksi tai lyhyeksi aikaa. Näin syntyy ristiriitaisia haluja ja ristiriitaista käyttäytymistä." (Ollilla, Maija-Riitta. 2010. Johtajan parempi elämä, s. 33)
Koko kuva ja yhteisöllisyys eivät siis aukea innovatiivisilla, organisaation toiminnan esittelyyn tarkoitetuilla lauseilla. Eri laumojen jäseninä emme siis toimikaan organisaatiokansalaisen tavoin, yksimielisesti.

\section{ORGANISAATIOKULTTUURISTA TYÖKULTTUURIN TARKASTELUUN}

Jotta kykenemme hahmottamaan amk-opettajien erilaiset yhteisöt ison organisaation sisällä, tarvitsemme tarkempia luuppeja kuin organisaatiokulttuuri. Tarkemman kurkistusikkunan meille tarjoaa työkulttuuri. Työkulttuurilla tarkoitetaan työyhteisön kokonaisuutta, joka rakentuu kollektiivisista ja kirjoittamattomista oikean ja väärän, sankaruuden ja antisankaruuden, oman kielen, yhteisten juhlien ja perinteiden, artefaktien, symbolien sekä arvotulkintojen kokemuksista.

Hyvänä esimerkkinä käy tässä tapauksessa amkkieli. Se kuin heimokieli, jossa on paikallisia murteita ja painotuksia. Ulkopuolisille se kuulostaa erilaiselta konsonanttipuheelta ja lyhenteiltä, joita on vaikea ymmärtää. Meillä on heksimme, piksimme, TKImme, LbDmme, PBLämme, joilla pyrimme kuvaamaan toimintaamme, työkalujamme ja pedagogista otettamme.

Kaiken kaikkiaan työkulttuurien elementit siirtyvät helposti työntekijältä toiselle. Ja huomatkaa: ne ovat eräs voimakkaimmista työtä kollektiivisesti ohjaavista tekijöistä. (Halava \& Pantzar 2010. Kuluttajakansalaiset tulevat. Miksi työn johtaminen muuttuu?)

Työkulttuureilla on lukemattomia kasvualustoja organisaation sisällä. Niitä ovat muiden muassa opettajien tiede- ja / tai ammattialataustat, eri koulutusohjelmien yhteisöt, monenlaiset hankeryhmät organisaation sisällä ja asiakasrajapinnoilla sekä mahdollisesti yhteiset työhistoriat kollegojen kanssa tai työhuonekumppanuus. Työkulttuureja voi olla useita organisaation sisällä niin sanotun organisaatiokulttuurin alla. Samassa työyhteisössä tai työryhmässä voi työskennellä taustaltaan monesta eri työkulttuuriorientaatiosta tulevia asiantuntijoita. Meillä kaikilla on omat henkilökohtaiset työorientaatiomme, jotka näkyvät yhteistyötilanteissa, erilaisina sitoutumisina ja kehittämishalukkuutena tai haluttomuutena. 
On tilanteita, joissa työkulttuurit voivat olla ristiriidassa vallitsevan organisaation valtakulttuurin kanssa. Työn arjessa, ihmisten toiminnasta johtuen, syntyy paradokseja, jotka ovat tyypillisiä asiantuntijayhteisöille. Esimerkiksi: opettajana me pidämme itsestään selvyytenä ohjaajan rooliamme suhteessa opiskelijaan, mutta esimiehen ohjauksen kohteena meidän saattaa olla hankala olla. Paradoksien kehittymiselle otollinen maaperä on amk-opettajan keskeisissä työtä ohjaavissa elementeissä. Niitä syntyy ihmiskäsitysten, johtamiskäsitysten, pedagogisten ismien, tutkimus- ja kehittämistyön arvostuksen, ajanhallinnan ja työelämäyhteistyön ympärille. Nämä samat elementit ovat myös työkulttuurien avaintekijöitä. Poikkeavat tulkinnat niistä muokkaavat eri toimintatapoja ja käsityksiä eri työkulttuureissa.

Eri organisaation toimijoiden kesken syntyy eri ryhmille erilaisia tulkintoja keskeisistä elementeistä. Ne alkavat elää omaa elämäänsä ja muokkaavat ryhmän, yhteisön työkulttuuria. Me emme olekaan tekemisissä niin usein faktojen kanssa, kun kiivailemme työyhteisössä niin sanotun oikean pedagogiikan tai ismin puolesta tai syytämme jäykkää opetussuunnitelmaa, joka estää työelämäläheisen työskentelyn tai johtamisen toimintatapoja. Me olemme tekemisissä omien ja toisten tulkintojen kanssa yhteisistä asioista tai toimintaa ohjaavista elementeistä.

\section{YHTEISÖLLISYYS KUIN MOSAIIKKIA}

Lektioni alun poimimissani ammattikorkeakouluesimerkeissä korostettiin yhteisöllisyyttä. Millaista yhteisöllisyyttä on järkevää tavoitteilla monialaisessa ja muotoisessa ammattikorkeakouluorganisaatiossa? Onko ylipäätään mahdollista saavuttaa toimivaa yhteisöllisyyttä? Voimme yrittää uskoa ja valuttaa pitkin organisaatiota juhlallisia ME-puheita laihoin tuloksin. Toisaalta voimme tarkastella moninaisuutta organisaatiossa mosaiikkisen lasiteoksen synnyttämän mielikuvan kautta. Läheltä katsottuna mosaiikkinen teos näyttää erikokoisten ja väristen palojen joukolta vailla logiikkaa. Mutta kun siirrymme etäämmälle tarkastelemaan teosta, huomaamme niiden pinnoiltaan olevan kiinni toisissaan ja muodostavan yhteisen esittävän teoksen. Kukin erikokoinen ja värinen pala tuo oman lisänsä teokseen ja täydentää sen monipuolisuutta.
Niin organisaation johto, työyhteisöt kuin yksittäiset asiantuntijat (tässä tapauksessa opettajat) tarvitsevat työkulttuuriosaamista. Meillä täytyy olla kyky tunnistaa ja tunnustaa erilaisten työkulttuurien olemassaolo organisaation sisällä kuin myös eri toimintaympäristöissä elinkeinoelämän ja opiskelijoiden kanssa tehtävissä erilaisissa projekteissa.

Jotta kykenemme onnistuneeseen yhteistyöskentelyyn eri työkulttuuritaustaustaisten asiantuntijoiden tai yhteisöjen kanssa tarvitsemme yhteisö- ja verkosto-osaamista. Meillä tulee olla kykyä tunnistaa erilaiset toimintaympäristömme, kykyä ymmärtää eri työkulttuuritaustaisten asiantuntijoiden toimintaa, kykyä yhteiseen työkielen löytämiseen sekä kykyä rakentaa yhdessä (vaikka vain hetkeksi) yhteisiä toimintatapoja eri taustoistamme huolimatta.

Tällainen työkulttuurillinen osaaminen parhaimmillaan kääntyy yhteisen osaamisen tuottamiseksi. Yhteinen osaaminen vaatii meiltä kykyä havaita monitoimijaisessa hankkeessa tiedon ja osaamisen ns. risteykset ja nostaa ne esille. Tärkeää on kyky omaksua toisen kokemuksista - eli siis kuunnella aidosti toisen puhetta ja havainnoida toimintaa. Edellä mainittu on usein opettajille erittäin haasteellista. Tämän jälkeen tulee olla kykyä suhteuttaa omaa osaamista muiden osaamisen kanssa ja mahdollisesti saada aikaan jotain uutta yhdessä, jota yksin emme koskaan olisi saaneet tehtyä.

Puheenvuoroni lopuksi kokoan kolmelle tasolle työkulttuurisen osaamisen tärkeyden.

\section{ASIANTUNTIJAORGANISAATIOTASO}

Tällä tasolla kyky tunnistaa ja toimia erilaisten työkulttuuritaustaisten yhteisöjen ja yksilöiden kanssa muuttaa ja laajentaa johtamista. Se tuo yksilöjohtamisen, ylhäältä alas valuttamisen rinnalle, jaetun johtamisen. Kollegani Mika Saranpää kanssa olemme muutaman vuoden ajan tutkineet ja valmentaneet johtamista koulutusorganisaatioissa. Olemme päätyneet tarkastelemaan johtamista johtamistoiminnan näkökulmasta. Johtaminen on toimintaa, johon me kaikki osallistumme, emme ole vain johtamisen kohteita, tahdottomia lihamöhkäleitä. Johtamisessa on silloin syytä panostaa mosaiikin palasia yhdistäviin alueisiin. Yhteisöllisyyttä on järkevä rakentaa tietyille 
tasoille ja autonomisuutta on syytä mahdollistaa eri yhteisöille asiakasrajapinnoilla.

Opettajien on yhä selvemmin opittava hahmottamaan oma lähiesimies uskottavana johtajana ja tukijana. AMK-matkani varrella olen liian usein törmännyt vanhan ajan "kyläkoulu-unelmointiin", jossa ainoa uskottava esimies on rehtori. Kutsun sitä vääränlaiseksi rehtorikaipuuksi. Tässä myös organisaatiokulttuuri voisi olla asian edistäjänä.

Organisaatiotasolla on myös tärkeää tulkita yhdessä työtämme ohjaavia keskeisiä käsitteitä ja toimintatapoja. Meidän tulee rakentaa tulkintafoorumeja eri työkulttuurien välille. Tulkintafoorumeilla meidän tulee työstää yhteistä ymmärrystä - ei välttämättä yhteisymmärrystä - yhteisestä suunnasta ja tavasta päästä sinne. Samoja toimenpiteitä tulee esiintyä välineinä kehityskeskusteluissa ja henkilöstökokouksissa. Tulkintafoorumityöskentelyt kehittävät neuvottelukulttuuria viestittelyn ja jalkautusten sijaan. Tämä luo työn hallinnan tunnetta, joka tuntuu olevan osaltaan kadoksissa asiantuntijatyössä.

\section{YKSILÖTASOLLA}

Henkilökohtaisella asiantuntijatyön tasolla yhteisöja verkosto-osaaminen on merkittävä mahdollistaja ja näkökulman avartaja omassa työssä. Kun ymmärrämme ja osaamme toimia eri työkulttuuritaustaisten henkilöiden (olivat he opiskelijoita, oman talon muita kollegoita tai elinkeinoelämän asiantuntijoita) kanssa pystymme kehittämään yhteisöllisiä työmenetelmiä ja toimintatapoja yhdessä. Yhteisö- ja verkosto-osaaminen auttavat meitä hanketyöskentelyissä ja kehittämään aidosti niin sanottua kolmikantaa amk-työssämme. Kolmikannalla tarkoitan opettajiston, opiskelijoiden ja elinkeinoelämän toimijoiden kanssa tehtävää yhteistyötä.

Käsityksemme ja ymmärryksemme erilaisista johtamiskulttuureista avartuvat. Näemme samalla itsemme osana johtamistoimintaa, joko luomassa kapuloita rattaisiin ja tukemalla sitä.

\section{OPETTAJATUTKIMUKSESSA}

Opettajatutkimus on ollut erittäin aktiivista ja kohdistunut usein muiden muassa opettajan osaamisvaatimuksiin ja ammatti-identiteetin tarkasteluun.
Empirian tuojina ovat olleet joko opettajat, opettajien esimiehet, opiskelijat tai työelämä. Kukin ryhmä on tuottanut vaatimuslistaa. Työkulttuurinen näkökulma on ollut tarkastelunäkökulmana vähäisempi. Mielestäni olisi paikallaan siirtää tarkastelua työkulttuurien suuntaan. Isot organisaatiot pitivät sisällään useita eri työkulttuuriheimoja, joiden elämä on tutkimuksen arvoista. Se tuo osaamisen johtamiselle, yhteisöllisyydelle ja sitoutumiselle aivan uusia haasteita ja problematisoi lähtökohtia. Emme ole välttämättä aina "yhtä suurta perhettä" ja etene linjassa strategian osoittamaan suuntaan. Mitään ei tule ottaa annettuna lähtökohtana, kun tutkii asiantuntijatyötä.

Työkulttuurilla on siis keskeinen merkitys, kun jäsennämme omaa työtä, pohdimme osaamisvaatimuksia ja sitoutumista. Työkulttuurien tunnustamisen taito ja erilaisuuden huomioiminen fuusioissa, yt-neuvotteluissa ja muissa muutostsunameissa avartaa katsetta kaikissa asiantuntijaorganisaatioissa olivatpa ne kouluja tai yrityksiä. Jotain tässä MaijaRiitta Ollilan toteamuksessa siis on ...

"Kaikista näistä laumoista omaksumme joitakin arvoja osaksi omaa persoonallisuuttamme joko pitkäksi tai lyhyeksi aikaa. Näin syntyy ristiriitaisia haluja ja ristiriitaista käyttäytymistä."

Lectio praecursoria 13.1.2012. Vastaväittäjänä toimi dosentti Pentti Rauhala Tampereen yliopistosta ja kustoksena professori Matti Koiranen Jyväskylän yliopistosta.

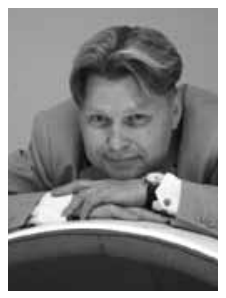

Kimmo Mäki yliopettaja HAAGA-HELIA ammattikorkeakoulu, Ammatillinen opettajakorkeakoulu 